ISSN 1392-3196 / e-ISSN 2335-8947

Zemdirbyste-Agriculture, vol. 101, No. 4 (2014), p. 425-430

DOI 10.13080/z-a.2014.101.054

\title{
Evaluation of eyespot incidence and structure of Oculimacula spp. population in winter rye in Lithuania
}

\author{
Jūrate RAMANAUSKIENE ${ }^{1}$, Irena GAURILČIKIENE ${ }^{1}$, Skaidre SUPRONIENE ${ }^{1}$, \\ Antanas Ronis $^{1}$, Rūta ČESNULEVIČIENÉ2 ${ }^{2}$ \\ ${ }^{1}$ Institute of Agriculture, Lithuanian Research Centre for Agriculture and Forestry \\ Instituto 1, Akademija, Kèdainiai distr., Lithuania \\ E-mail: jurate.ramanauskiene@1zi.lt \\ ${ }^{2}$ Perloja Experimental Station, Lithuanian Research Centre for Agriculture and Forestry \\ Sodo 12, Perloja, Varèna distr., Lithuania
}

\begin{abstract}
Eyespot of rye, caused by two fungal pathogens Oculimacula yallundae and $O$. acuformis, is widespread throughout many cool and wet cereal growing regions. The study was aimed to estimate eyespot incidence in winter rye crops in three agro-ecological zones of Lithuania, and to quantify eyespot disease causal agents $O$. yallundae and $O$. acuformis in the population using the real-time polymerase chain reaction (RT PCR) method. During the 2008-2012 periods, 69 winter rye fields were surveyed and eyespot-affected stems were identified in $92.7 \%$ of the crops surveyed. The incidence of eyespot in winter rye crops varied from $8.0 \%$ to $82.7 \%$ depending on the year and location. The average disease incidence in the reviewed crops was $26.0 \%$. The highest incidence of eyespot averaging $34.0 \%$ was identified in the winter rye crops of the Middle Lowland zone. Both eyespot causal agents $O$. yallundae and $O$. acuformis were often found to co-exist on the winter rye stems. In the majority of the winter rye crops tested, $O$. acuformis was predominant in the Oculimacula spp. population. In most cases, O. yallundae was identified only at trace-level concentrations.
\end{abstract}

Key words: eyespot, Oculimacula acuformis, O. yallundae, real-time polymerase chain reaction, Secale cereale.

\section{Introduction}

Among cereal species grown in Lithuania, winter rye is an important plant for bread and is best suited to grow in temperate climates. It produces a high and stable, high-quality yield of grain. Rye is very resistant to frost; its root system can take up nutrients from the deepest soil layers, so it can grow well on soils that are not suitable for growing other cereals such as wheat or barley (Bolibok et al., 2005).

Eyespot is one of the most important stem base diseases of cereals caused by the two fungi Oculimacula yallundae (Wallwork \& Spooner) Crous \& W. Gams, anamorph Helgardia herpotrichoides (Fon) Crous \& W.Gams, and O. acuformis (Boerema, R.Pieters \& Hamers) Crous \& W.Gams, anamorph Helgardia acuformis (Nirenberg) Crous \& W.Gams (Crous et al., 2003). Eyespot is widespread throughout many cool and wet cereal growing regions: temperate climate regions in Europe, especially in West European countries - the United Kingdom, Germany, France, as well as in our neighbouring country Poland, and similarly in South Africa, North America, Australia (Cromey et al., 2006; Glazek, 2009). Eyespot incidence is strongly influenced by the weather conditions; spores are formed in wet conditions only and are splashed by rain (Vanova et al., 2005). The risk of incidence depends on many other factors such as sowing time, soil type, tillage methods, crop rotation (Bock et al., 2009; Jenkyn et al., 2010;
Burnett et al., 2012). This disease is particularly significant in agricultural systems with reduced rotation, because both pathogens can infect perennial grasses of the Poaceae family and a wide range of cereals including rye (Meyer et al., 2011). Under favourable conditions, eyespot can damage spring cereals too. According to Lemanczyk (2009) data, the greatest disease incidence $(\mathrm{DI}=53.1 \%)$ of eyespot in spring rye was established in the year when the total rainfall was highest. In Lithuania, the incidence of eyespot in cereal crops varied depending on the year and site (Gaurilčikienè, 1998; Janušauskaitè, Čiuberkis, 2010). The symptoms of eyespot are eyeshaped, elliptical lesions on the lower internodes, which disrupt the transport of water and nutrients and predispose the plant to collapse. O. yallundae is a more specialised causal agent of wheat eyespot and is often referred to as $\mathrm{W}$ (wheat) type; however, it can affect other Poaceae plants, while $O$. acuformis is equally pathogenic on rye, wheat and barley and is referred to as $\mathrm{R}$ (rye) type. The symptoms on plants caused by $O$. yallundae and $O$. acuformis visually do not differ (Ray et al., 2006); however, they differ in pathogenicity and occurrence (Fitt et al., 2006). Visual assessment of individual pathogens in mixed infection is often difficult, because other stem base and root rot diseases have similar symptoms. Polymerase chain reaction (PCR) method is often used in research for positive diagnosis and quantification of 
pathogens including Oculimacula spp. (Nicholson et al., 1997). Studies have shown that a higher incidence of eyespot is established using PCR method compared with visual assessment (Jackson et al., 2007). RT PCR assay is much faster and more accurate. This method was used to quantify Oculimacula spp. in the eyespot-diseased winter rye stems (Walsh et al., 2005). In Lithuania, the ratio of $O$. yallundae to $O$. acuformis in the population has not been studied before.

The research was aimed to estimate eyespot incidence in winter rye crops in different agro-ecological zones of Lithuania, and to quantify eyespot disease causal agents Oculimacula yallundae and O. acuformis in the population using the real-time polymerase chain reaction (RT PCR) method.

\section{Materials and methods}

Assessment of eyespot incidence, field samples. To estimate eyespot incidence in winter rye in Lithuania, plant samples were collected in 2008-2012 from the farms of agricultural partnerships and private farmers. The sampling was done at cereal ripening stage $(\mathrm{BBCH}$ 85-89) in different agro-ecological zones of the country: in the Middle Lowland from 13 administrative districts, in Western zone from 8 and in Eastern zone from 11 . A total of 250 stems (50 stems from 5 places) from a field were randomly collected for eyespot incidence assessments. Eyespot diseased stems were counted and the disease incidence (percentage of diseased stems) was determined. The lower three internodes of infected stems were cut off, labelled and stored in fabric bags in a refrigerator for further analyses.

Investigation of Oculimacula spp. population structure. Deoxyribonucleic acid (DNA) extraction. Fungal DNA was extracted from rye stems. Each sample collected from commercial fields was composed of 10 randomly selected eyespot-affected stems. Stem segments approximately $2.5 \mathrm{~cm}$ in size (Bateman et al., 2000) were ground in a Cyclotec ${ }^{\mathrm{TM}} 1093$ mill (FOSS, Denmark) and homogenised in liquid nitrogen. DNA was extracted from $0.1 \mathrm{~g}$ homogenised sample in two replications using a commercial GenElute Plant Genomic DNA Miniprep Kit (Sigma-Aldrich, USA).

Real-time polymerase chain reaction (RT PCR). The standard curve (absolute quantitation, AQ) method was used for $O$. yallundae and $O$. acuformis DNAquantification in eyespot-affected stems of winter rye. Plant EF $1 \alpha$ Hor $1 F$ and Hor $2 \mathrm{R}$ primers were used to normalize reactions (Nicolaisen et al., 2009). The volume per reaction was $20 \mu \mathrm{l}$ consisting of $10 \mu \mathrm{l}$ Maxima ${ }^{\mathrm{TM}}$ SYBR Green qPCR Master Mix (Thermo Fisher Scientific, Lithuania), $6.9 \mu \mathrm{l}$ water (nuclease free), $0.3 \mu \mathrm{l} \mathrm{Ocu-R}$ and $0.3 \mu \mathrm{l}$ YallFHF, $0.3 \mu \mathrm{l}$ Ocu-R and 0.3 $\mu \mathrm{l} \mathrm{AcFDF}$ or $0.3 \mu \mathrm{l}$ Hor $1 \mathrm{~F}$ and $0.3 \mu \mathrm{l}$ Hor $2 \mathrm{R}$ and $2.5 \mu \mathrm{l}$ DNA (Table 1). For development of standard curves of Oculimacula spp. fungi, DNA was isolated from pure $O$. yallundae and $O$. acuformis cultures, obtained from BCCM/IHEM Biomedical Fungi and Yeasts Collection, the Mycology Laboratory at the Scientific Institute of Public Health in Brussels (Belgium). DNA extracted from wheat (Triticum aestivum L.) leaves was used for standard curve of plants. To normalize reactions, plant DNA was used from the same sample as the fungus analysed. DNA sample $\left(\mathrm{mg} \mathrm{ml}^{-1}\right)$ concentrations were checked by a Biophotometer (Eppendorf, Germany). Individual standard curves were formed from different concentrations of DNA of the tested fungi and plants, having done 5 dilutions of the initial DNA sample. For $O$. yallundae standard curve we used 45 to $0.000045 \mathrm{ng}^{-1} \mathrm{l}^{-1}$,

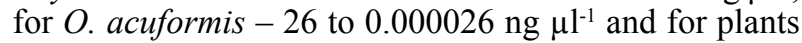

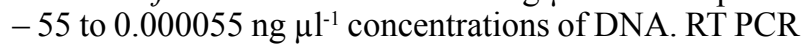
was performed on a 7900HT Fast, Sequence Detection System (Applied Biosystems, USA) using the following cycling regime: $95^{\circ} \mathrm{C}-10 \min \left(95^{\circ} \mathrm{C}-15 \mathrm{~s}, 60^{\circ} \mathrm{C}-\right.$ $\left.30 \mathrm{~s}, 72^{\circ} \mathrm{C}-1 \mathrm{~min}\right)^{40 \text { cycles }}$. RT PCR of one sample was performed in three replicates.

Table 1. Specific primers and their sequences used for real-time polymerase chain reaction (RT PCR) analyses

\begin{tabular}{lcc}
\hline \multicolumn{1}{c}{ Target } & Primer & Sequence (5'-3') \\
\hline Oculimacula acuformis & AcFDF & GCCACCCTACTTCGGTAA \\
O. yallundae & YallFHF & GGGGGCTACCCTACTTGGCAG \\
Oculimacula spp. & Ocu-R & ATTCAAGGGTGGAGGTCTGRA \\
Triticum aestivum $\mathrm{L}$. & WpalF & CGTTCTTGGTCGCGTTGTG \\
& WpalR & ACTCTTGACAGCATTCTTGACATTCT \\
Plant EF1 $\alpha$ & Hor1F & TCTCTGGGTTTGAGGGTGAC \\
& Hor2R & GGCCCTTGTACCAGTCAAGGT \\
\hline
\end{tabular}

For the results of eyespot incidence and amounts of fungal DNA, a standard deviation was calculated using the statistical data processing software Stat Eng. Tables present standard deviation (SD), mean, the least (Min) and the highest (Max) disease incidence.

\section{Results}

The incidence of eyespot in winter rye. During the period 2008-2012, in Western zone of Lithuania 17 fields, in the Middle Lowland 23 fields and in Eastern zone 29 fields of winter rye were inspected for eyespot incidence (Table 2). Eyespot was identified in $92.7 \%$ of the surveyed winter rye crops. The incidence of eyespot in assessed winter rye crops markedly varied between locations and years. In 69 rye fields assessed during 2008 2012 the eyespot incidence averaged 26.0\%. Depending on the year, the disease incidence in different locations varied from $8.0 \%$ to $82.7 \%$. The highest incidence was identified in the Middle Lowland zone in 2009 (82.7\%) and the lowest in the Eastern zone in 2011 (8.0\%). According to the data averaged over five years, the highest eyespot incidence was in Middle Lowland (34.0\%) and the lowest in Eastern zone (18.6\%), while in Western zone eyespot affected $25.3 \%$ of winter rye stems.

Oculimacula spp. population structure in winter rye crops. Both eyespot causal agents $O$. yallundae and $O$. acuformis were often found to co-exist on the winter rye stems. The concentrations of $O$. yallundae and $O$. acuformis DNA in winter rye stems varied between experimental years and sites. Of all the samples of winter rye collected during 2010-2012, the highest DNA concentrations of the pathogens were detected in those collected in 2012, while the lowest concentrations were identified in the ones collected in 2010 (Table 3). In almost all winter rye crops tested, O. acuformis predominated in the Oculimacula spp. population, except only in one crop in 2012 in Jonava where the amount 
Table 2. The incidence of eyespot (\%) in winter rye in three agro-ecological zones of Lithuania during in 2008-2012

\begin{tabular}{|c|c|c|c|c|c|c|}
\hline \multirow[b]{2}{*}{ District } & \multicolumn{6}{|c|}{ Experimental year } \\
\hline & 2008 & 2009 & 2010 & 2011 & 2012 & $\begin{array}{c}\text { Average } \\
2008-2012\end{array}$ \\
\hline \multicolumn{7}{|c|}{ Western zone } \\
\hline Kelmè & $*$ & - & 26.0 & 32.0 & - & 29.0 \\
\hline Klaipèda & 4.0 & 16.3 & - & - & 28.0 & 16.1 \\
\hline Raseiniai & - & - & 28.0 & 32.0 & - & 30.0 \\
\hline Plungè & - & - & - & - & 44.0 & 44.0 \\
\hline Šilalè & - & - & - & 23.0 & - & 23.0 \\
\hline Šilutè & - & - & - & - & 4.0 & 4.0 \\
\hline Tauragè & 24.0 & - & - & - & 20.0 & 22.0 \\
\hline Telšiai & 20.0 & 65.3 & - & 0 & 52.0 & 34.3 \\
\hline Average & $16.0(n * *=3)$ & $40.8(n=2)$ & $27.0(n=3)$ & $21.8(n=4)$ & $29.6(n=5)$ & $25.3(n=17)$ \\
\hline $\mathrm{SD}$ & 10.58 & 27.58 & 1.41 & 2.31 & 19.10 & 14.95 \\
\hline \multicolumn{7}{|c|}{ Middle Lowland } \\
\hline Biržai & - & - & 20.0 & - & - & 20.0 \\
\hline Jonava & - & - & - & - & 68.0 & 68.0 \\
\hline Jurbarkas & - & - & - & 0 & 20.0 & 10.0 \\
\hline Kaišiadorys & - & - & 4.0 & 12.0 & 20.0 & 12.0 \\
\hline Kaunas & 8.0 & - & - & - & - & 8.0 \\
\hline Kèdainiai & 76.0 & 88.0 & 36.0 & 8.0 & 48.0 & 51.2 \\
\hline Marijampolè & 55.0 & 84.0 & - & - & - & 69.5 \\
\hline Panevėžys & 23.0 & - & - & - & - & 23.0 \\
\hline Pasvalys & - & 76.0 & - & - & - & 76.0 \\
\hline Prienaí & - & - & 8.0 & - & 36.0 & 22.0 \\
\hline Radviliškis & - & - & - & 28.0 & - & 28.0 \\
\hline Šakiai & - & - & - & 12.0 & - & 12.0 \\
\hline Šiauliai & 40.0 & - & - & - & 44.0 & 42.0 \\
\hline Average & $40.4(n=5)$ & $82.7(n=3)$ & $17.0(n=4)$ & $12.0(n=5)$ & $39.3(n=6)$ & $34.0(n=23)$ \\
\hline $\mathrm{SD}$ & 26.61 & 6.21 & 14.38 & 8.87 & 18.32 & 31.60 \\
\hline \multicolumn{7}{|c|}{ Eastern zone } \\
\hline Alytus & 28.0 & - & - & - & - & 28.0 \\
\hline Anykščiai & 18.0 & 28.0 & 16.0 & 0 & 20.0 & 16.4 \\
\hline Ignalina & 33.0 & - & - & - & - & 33.0 \\
\hline Molètai & - & - & - & 20.0 & 20.0 & 20.0 \\
\hline Rokiškis & - & - & - & 0 & - & 0 \\
\hline Šalčininkai & - & - & 16.0 & - & - & 16.0 \\
\hline Trakai & - & - & - & 4.0 & - & 4.0 \\
\hline Ukmergè & - & - & 0 & 16.0 & 32.0 & 16.0 \\
\hline Utena & - & 4.0 & - & - & - & 4.0 \\
\hline Varèna & 33.4 & - & 30.0 & - & 50.0 & 37.8 \\
\hline Vilnius & 16.0 & - & 36.0 & - & 36.0 & 29.3 \\
\hline Average & $25.7(n=10)$ & $16.0(n=2)$ & $19.6(n=6)$ & $8.0(n=5)$ & $31.6(n=6)$ & $18.6(n=29)$ \\
\hline $\mathrm{SD}$ & 8.23 & 16.97 & 14.03 & 8.33 & 12.52 & 9.79 \\
\hline Average in Lithuania & $29.1(n=18)$ & $53.2(n=7)$ & $20.0(n=13)$ & $13.7(n=14)$ & 33.5(n=17) & $26.0(n=69)$ \\
\hline SD & 19.45 & 33.3 & 12.43 & 10.29 & 16.45 & 14.95 \\
\hline Min & 4.0 & 4.0 & 0 & 0 & 4.0 & 0 \\
\hline Max & 76.0 & 88.0 & 36.0 & 32.0 & 68.0 & 88.0 \\
\hline
\end{tabular}

* - not assessed, ** - number of crops assessed; SD - standard deviation, Min - the least disease incidence, Max - the highest disease incidence

of both $O$. acuformis and $O$. yallundae was comparable, and in 2011 in one crop in Anykščiai where $O$. yallundae outnumbered $O$. acuformis. In most cases, $O$. yallundae was identified at trace-level concentration. The highest amount of O.acuformis DNA was established in the sample collected in Kaišiadorys in 2012, it is almost twice as much as in Telšiai, Ukmergè, Vilnius and Molètai. A similar amount of both pathogens was established in 2010 in Raseiniai, Kelmè and Šalčininkai, in 2011 in Telšiai, Radviliškis, Kaišiadorys and Anykščiai, and in 2012 in Silute and Jonava. In all tested samples from Western zone and from Middle Lowland (Kèdainiai, Šiauliai and Prienai districts) the amount of $O$. yallundae DNA was identified at trace-level concentrations.

The averaged data of $O$. yallundae and O. acuformis DNA concentration in eyespot-infected winter rye stems differed between agro-ecological zones annually (Fig.). In 2010, the amount of DNA of O. yallundae in Middle Lowland and Eastern zone was identified at very low concentration, whereas $O$. acuformis was determined in all samples from all agro-ecological zones, and in Middle Lowland was five times as high as in Western and Eastern zones. In 2011, the highest concentrations of the $O$. acuformis DNA were detected in the samples collected in Eastern zone, which were three times higher than in those from the Middle Lowland and twice as high as in the ones from the Western zone. The amount of DNA of $O$. yallundae in winter rye samples from all locations was very low, and in Western and Middle Lowland zones only trace-level concentrations were identified. In 2012, the largest amount of DNA of both fungus species was determined. That year, in Eastern zone the amount of $O$. acuformis DNA was 18 times higher than that of $O$. yallundae, in Middle Lowland 31 times and in Western zone as many as 112 times. In 2011 and 2012, the greatest amount of $O$. acuformis DNA was detected in the samples from Eastern zone, which was probably caused by rye domination in the crop rotation 
Table 3. The amount of deoxyribonucleic acid (DNA) of Oculimacula yallundae and O. acuformis in winter rye samples collected in Lithuanian fields in 2010-2012

\begin{tabular}{|c|c|c|c|c|c|c|}
\hline \multirow{3}{*}{ District } & \multicolumn{6}{|c|}{ Oculimacula spp. DNA (fungal DNA ng / plant DNA ng) } \\
\hline & \multicolumn{2}{|c|}{2010} & \multicolumn{2}{|c|}{2011} & \multicolumn{2}{|c|}{2012} \\
\hline & O. yallundae & O. acuformis & O. yallundae & O. acuformis & O. yallundae & O. acuformis \\
\hline \multicolumn{7}{|c|}{ Western zone } \\
\hline Kelmé & 0.036 & 0.050 & 0.236 & 7.371 & - & - \\
\hline Klaipèda & - & - & - & - & 0.154 & 31.346 \\
\hline Raseiniai & 1.714 & 3.079 & 0.086 & 1.300 & & \\
\hline Plungè & - & - & - & - & 0.049 & 27.205 \\
\hline Šilalè & - & - & 0.005 & 4.878 & - & - \\
\hline Šilutė & - & - & - & - & 0.439 & 3.794 \\
\hline Telšiai & - & - & 0.093 & 0.190 & 0.795 & 117.315 \\
\hline \multicolumn{7}{|c|}{ Middle Lowland } \\
\hline Biržai & 0.134 & 12.350 & - & - & - & - \\
\hline Jonava & - & - & - & - & 4.723 & 4.701 \\
\hline Kaišiadorys & 0.003 & 0.044 & 0.011 & 0.057 & 3.171 & 211.030 \\
\hline Kèdainiai & 0.246 & 2.436 & 0.038 & 7.269 & 0.034 & 5.879 \\
\hline Prienai & 0.301 & 17.387 & - & - & 0.061 & 34.737 \\
\hline Radviliškis & - & - & 0.052 & 0.299 & - & - \\
\hline Šiauliai & - & - & - & - & 0.581 & 10.524 \\
\hline \multicolumn{7}{|c|}{ Eastern zone } \\
\hline Anykščiai & 0.019 & 2.999 & 0.332 & 0.238 & - & - \\
\hline Molètai & - & - & 0.475 & 9.684 & 1.661 & 65.836 \\
\hline Šalčininkai & 0.205 & 0.594 & - & - & - & - \\
\hline Trakai & - & - & 4.475 & 10.962 & - & - \\
\hline Ukmergè & - & - & - & - & 4.107 & 94.718 \\
\hline Vilnius & 0.006 & 1.076 & - & - & 9.678 & 118.435 \\
\hline Standard deviation & 0.350 & 6.150 & 1.380 & 4.390 & 2.910 & 93.870 \\
\hline The least amount & 0.0 & 0.04 & 0.01 & 0.06 & 0.03 & 3.79 \\
\hline The highest amount & 1.11 & 17.39 & 4.48 & 10.96 & 9.68 & 211.03 \\
\hline
\end{tabular}

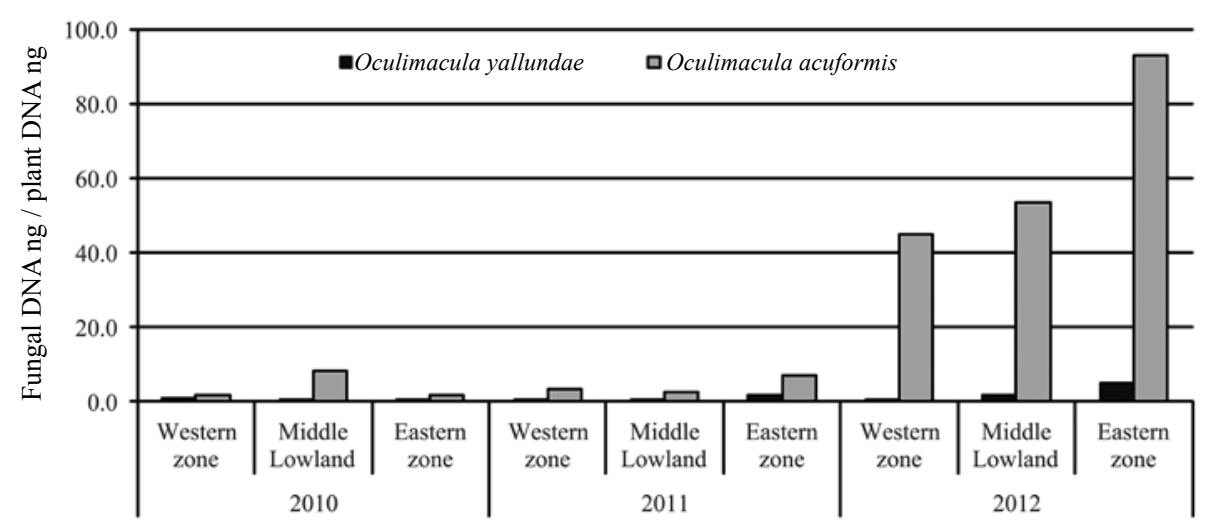

Figure. Oculimacula yallundae and $O$. acuformis deoxyribonucleic acid (DNA) in the winter rye stem-base from three agro-ecological zones of Lithuania (real-time polymerase chain reaction (RT PCR) absolute quantification (AQ) method)

in this agro-ecological zone. Low productivity soils in Eastern zone are more suitable for rye than for wheat in comparison with Middle Lowland and Western zone.

\section{Discussion}

The findings of the 2008-2012 field surveys indicated that the incidence of eyespot in winter rye differed between years, locations and fields. Research done in Lithuania in previous years also showed differences in eyespot incidence between years and locations. In 1994-1996, in Dotnuva, Kedainiai distr., in tetraploid rye crops eyespot affected only single plants (Gaurilčikienè, 2000); however, in Vèžaičiai, Klaipėda distr., eyespotinfected rye stems accounted for 3.0-42.8\%, and Perloja, Varèna distr. - for $0.9-19.2 \%$. The most severe eyespot incidence was in early sown winter rye crops; however, the disease incidence varied depending on year conditions in particular agro-ecological zone (Gaurilčikienè, 1998). Crop rotation, soil type, sowing date, rainfall during spring period and cultivation method are crucial to the intensity of the disease (Burnett, 2005). In the current study, in rye crops inspected for eyespot presence all of these factors were different, which resulted in great dispersal of disease incidence data in different regions and fields.

Both $O$. yallundae and $O$. acuformis are widespread in many cereal production regions of the world, except for South Africa where only O. yallundae has been detected. Literature sources indicate that Oculimacula pathogens infect different plant species at different levels, are not specific to one host-plant species and are characterised by a wide specialization (Kayser, Heitefuss, 1992). O. acuformis has been reported to be equally identified in wheat and rye, while $O$. yallundae is more severe in wheat than in rye (Lucas et al., 2000). Both pathogens can co-exist on one stem and can cause 
symptoms of eyespot that visually hardly differ on various Poaceae family plants (Fitt et al., 1987). Previous investigations performed in Lithuania showed that both $O$. yallundae and $O$. acuformis were identified on eyespot diseased cereal stems according to fungi morphological characteristics as well as PCR test. Both eyespot fungi occurred at quite similar incidence on rye, wheat, triticale and barley stems and often co-existed on the same stem (Gaurilčikienè et al., 2010; Ramanauskienè et al., 2014). Pooling the averaged data on the quantity of $O$. yallundae and $O$. acuformis DNA concentrations in eyespot-infected winter rye stems, it was estimated that the quantities differed between years and agro-ecological zones annually (Fig.). Many researchers have reported that eyespot pathogen O. acuformis is dominant of Oculimacula spp. in cereals (Ray et al., 2004). According to our results, using RT PCR analysis, $O$. acuformis was clearly prevalent in the Oculimacula spp. population in the majority of rye crops tested; only in one field in Anykščiai (2011) O. yallundae DNA slightly exceeded $O$. acuformis, and in one field in Jonava (2012) DNA amount of both pathogens was equal (Table 3). O. yallundae usually developed earlier than $O$. acuformis. Nicholson et al. (2002) suggest that at stem elongation stage (BBCH 31-34) the amount of O. yallundae DNA was significantly higher than that of $O$. acuformis. This can be explained by the fact that at early plant growth stages $O$. yallundae infects plants and penetrates leaf sheaths more quickly than $O$. acuformis (Ray et al., 2006).

Both the eyespot incidence and concentrations of $O$. yallundae and $O$. acuformis DNA in winter rye stems varied between experimental years and sites. In the present study, from 2010-2012 the highest incidence of eyespot in winter rye crops was in 2012 and the lowest in 2011. In 2012, the highest concentration of $O$. acuformis DNA in eyespot infected rye stems was found too, while in 2010 and 2011 the amounts of pathogen DNA detected were considerably lower and comparable. However, eyespot incidence in separate fields most often was not corresponded with fungal DNA amounts from diseased stems (Tables 2-3). We did not find any literature to support the relationship between eyespot incidence and amounts of Oculimacula spp. DNA in rye crop. As has been reported by Turner et al. (2001), visual and PCR analyses on wheat stems generally supported each other, but there were often variances in relating disease incidence or the severity of symptoms to the amount of pathogen DNA by regression analyses; however, the relationships between symptoms and eyespot pathogen DNA were less clear on some cultivars. Ray at al. (2004) similarly indicated that the relationship between $O$. acuformis DNA and eyespot incidence or severity in wheat was weak.

In summary, the results presented in this study indicate that eyespot incidence in rye in some fields could be economically important, and that the prevalence of O.acuformis in the Oculimacula population is an important factor for eyespot control in rye crops.

\section{Conclusions}

1. Eyespot was identified in $92.7 \%$ of the winter rye crops inspected. The disease incidence averaged $26.0 \%$. It occurred at higher incidence rates in the winter rye crops in the Middle Lowland zone. Depending on the year and site, eyespot incidence varied from $8.0 \%$ to $82.7 \%$. The highest incidence was identified in the Middle Lowland zone in 2009, while the lowest incidence was recorded in the Eastern zone in 2011.

2. The concentrations of Oculimacula yallundae and $O$. acuformis deoxyribonucleic acid (DNA) in infected winter rye stems varied between experimental years and sites. Of all the samples of winter rye collected during 2010-2012, the highest DNA concentrations of the tested pathogens were detected in the samples collected in 2012, while the lowest concentrations were identified in those collected in 2010 . In the majority of winter rye crops tested, $O$. acuformis predominated in the Oculimacula spp. population, O. yallundae was identified at trace-level concentration.

\section{Acknowledgements}

The paper presents research findings, obtained through the long-term research programme "Harmful organisms in agro and forest ecosystems" (KOMAS) implemented by Lithuanian Research Centre for Agriculture and Forestry.

Received 21012014 Accepted 14092014

\section{References}

Bateman G. L., Edwards S. G., Marshall J., Morgan L. W., Nicholson P., Nuttall M., Parry D. W., Scrancher M., Turner A. S. 2000. Effects of cultivar and fungicides on stem-base pathogens, determined by quantitative PCR, and on diseases and yield of wheat. Annals of Applied Biology, 137 (3): 213-221 http://dx.doi.org/10.1111/j.1744-7348.2000.tb00062.x

Bock C. H., Wan A. M., Fitt B. D. 2009. Development of Oculimacula yallundae and $O$. acuformis (eyespot) lesions on stems of winter wheat in relation to thermal time in the UK. Plant Pathology. 58 (1): 12-22 http://dx.doi.org/10.1111/j.1365-3059.2008.01942.x

Bolibok H., Rakoczy-Trojanowska M., Hromada A., Pietrzykowski R. 2005. Efficiency of different PCR-based marker systems in assessing genetic diversity among winter rve (Secale cereale L.) inbred lines. Euphvtica. 146: 109-116 http://dx.doi.org/10.1007/s10681-005-0548-0

Burnett F. J. 2005. Validation of risk assessment method to identify wheat crops at risk from eyespot. HGCA, Project Report No. 347, Part 2

Burnett F., Butler-Ellis C., Hughes G., Knight S., Ray R. 2012. Forecasting eyespot development and yield losses in winter wheat. HGCA, Project Report No. 491

Cromey M. G., Parkers R. A., Fraser P. M. 2006. Factors associated with stem base and root diseases of New Zealand wheat and barley crops. Australasian Plant Pathology, 35: 391-400 http://dx.doi.org/10.1071/AP06032

Crous P. W., Groenewald J. Z., Gams W. 2003. Eyespot of cereals revisited: ITS phylogeny reveals new species relationships. European Journal of Plant Pathologv. 109 (8): 841-850 http://dx.doi.org/10.1023/A:1026111030426

Fitt B. D. L., Creighton N. F., Bateman G. L. 1987. Pathogenicity to wheat seedlings of wheat-type and rye-type isolates of Pseudocercosporella herpotrichoides. Transactions of the British Mycological Society, 88 (2): 149-155 http://dx.doi.org/10.1016/S0007-1536(87)80209-7

Fitt B. D. L., Huang Y., Bosch F., West J. S. 2006. Coexistence of related pathogen species on arable crops in space and time. Annual Review of Phvtonathologv. 44: 163-182 $\mathrm{http}: / / \mathrm{dx}$.doi.org/10.1146/annurev.phyto.44.070505.143417

Gaurilčikienè I. 1998. Investigation of the occurrence of fungal diseases on various sowing time and density tetraploid winter rye stands in different agroclimatic zones of Lithuania. Zemdirbyste-Agriculture, 62: 142-154 (in Lithuanian)

Gaurilčikienè I., Supronienè S., Ramanauskienė J. 2010. A survey of Oculimacula yallundae and $O$. acuformis population in different regions of Lithuania. Botanica Lithuanica, 16: 43-49

Glazek M. 2009. Occurrence of eyespot on winter wheat in the central-southern region of Poland. Journal of Plant Protection Research. 49 (4): 426-433 http://dx.doi.org/10.2478/v10045-009-0068-3 
Jackson E. W., Obert D. E., Menz M., Hu G., Avant J. B., Chong J., Bonman J. M. 2007. Characterization and mapping of oat crown rust resistance genes using three assessment methods. Phytopathology. 97 (9): 1063-1070 http://dx.doi.org/10.1094/PHYTO-97-9-1063

Janušauskaitė D, Ciuberkis S. 2010. Effect of different soil tillage and organic fertilizers on winter triticale and spring barley stem base diseases. Crop Protection. 29: 802-807 http://dx.doi.org/10.1016/j.cropro.2010.04.002

Jenkyn J. F., Gutteridge R. J., Bateman G. L., Jalaluddin M. 2010. Effects of crop debris and cultivations on the development of eyespot of wheat caused by Oculimacula spp. Annals of Applied Biology. 156 (3): 387-399 http://dx.doi.org/10.1111/j.1744-7348.2010.00396.x

Kayser A., Heitefuss R. 1992. Pathogenicity to wheat of isolates of Pseudocercosporella herpotrichoides (Fron) Deighton from five Graminaceous hosts. Journal of Phytopathology, 136 (4): $340-343$ http://dx.doi.org/10.1111/j.1439-0434.1992.tb01317.x

Lemanczyk G. 2009. Fungal diseases on roots and stem bases of spring rye cultivated in pure stand or in mixtures with other crops. Phytopathologia, 53: 31-41

Lucas J. A., Dyer P. S., Muray T. D. 2000. Pathogenicity, hostspecificity, and population biology of Tapesia spp., causal agents of eyespot disease in cereals. Advances in Botanical Research. 33: 226-258 http://dx.doi.org/10.1016/S0065-2296(00)33044-0

Meyer N., Lind V., Karlowsky P., Zahn M., Friedt W., Ordon F. 2011. Development of a real-time PCR methods for the identification of wheat genotypes carrying different evespot resistance genes. Plant Breeding. 130 (1): 16-24 http://dx.doi.org/10.1111/j.1439-0523.2010.01808.x

Nicholson P., Rezanoor H. N., Simpson D. R., Joyce D. 1997. Differentiation and quantification of the cereal eyespot fungi Tapesia yallundae and Tapesia acuformis using a PCR assav. Plant Pathology. 46 (6): 842-856 http://dx.doi.org/10.1046/j.1365-3059.1997.d01-74.x

Nicholson P., Turner A. S., Edwards S. G., Bateman G. L., Morgan L. W., Parry D. W. 2002. Development of stembase pathogens on different cultivars of winter wheat determined by quantitative PCR. European Journal of Plant Pathology, 108 (2): 163-177

http://dx.doi.org/10.1023/A:1015087311702

Nicolaisen M., Supronienè S., Nielsen L. K., Lazzaro I., Spliid N. H., Justesen A. F. 2009. Real-time PCR for quantification of individual Fusarium species in cereals. Journal of Microbiological Methods, 76 (3): 234-240 http://dx.doi.org/10.1016/j.mimet.2008.10.016

Ramanauskienè J. Gaurilčikienè I., Semaškienė R., Jonavičienė A. 2014. Incidence of eyespot on winter triticale and quantification of Oculimacula spp. population using realtime PCR in Lithuania. Acta Agriculturae Scandinavica, Section B: Soil and Plant Science, 64 (7): 559-605 http://dx.doi.org/10.1080/09064710.2014.939993

Ray R. V., Jenkinson P., Edwards S. G. 2004. Effects of fungicides on eyespot, caused predominantly by Oculimacula acuformis, and yield of early-drilled winter wheat. Cron Protection. 23 (12): 1199-1207 http://dx.doi.org/10.1016/j.cropro.2004.05.003

Ray R. V., Crook M. J., Jenkinson P., Edwards S. G. 2006. Effect of eyespot caused by Oculimacula yallundae and O. acuformis, assessed visually and by competitive PCR, on stem strength associated with lodging resistance and yield of winter wheat. Journal of Experimental Botany, 57 (10): 2249-2257 http://dx.doi.org/10.1093/jxb/erj192

Turner A. S., Nicholson P., Edwards S. G., Bateman G. L., Morgan L. W., Todd A. D., Parry D. W., Marshall J., Nuttall M. 2001. Evaluation of diagnostic and quantitative PCR for the identification and severity assessment of eyespot and sharn evesnot in winter wheat. Plant Pathology. 50: 463469 http://dx.doi.org/10.1046/j.1365-3059.2001.00592.x

Vanova M., Klem K., Matusinsky P., Spitzerova D. 2005. Prediction of evesnot infection risks. Acta Agrobotanica, 58 (1): 91-96 http://dx.doi.org/10.5586/aa.2005.014

Walsh K., Korimbocus J., Boonham N., Jennings P., Hims M. 2005. Using real-time PCR to discriminate and quantify the closely related wheat pathogens Oculimacula yallundae and Oculimacula acuformis. Journal of Phytopathology, 153 (11-12): 715-721

http://dx.dói.org/10.1111/j.1439-0434.2005.01045.x

ISSN 1392-3196 / e-ISSN 2335-8947

Zemdirbyste-Agriculture, vol. 101, No. 4 (2014), p. 425-430

DOI 10.13080/z-a.2014.101.054

\title{
Stiebalūžès išplitimas žieminiuose rugiuose ir jos sukẻlèjų Oculimacula spp. populiacijos įvairovė Lietuvoje
}

\author{
J. Ramanauskienè ${ }^{1}$, I. Gaurilčikienè ${ }^{1}$, S. Supronienè ${ }^{1}$, A. Ronis ${ }^{1}$, R. Česnulevičienè ${ }^{2}$ \\ ${ }^{1}$ Lietuvos agrarinių ir miškų mokslų centro Žemdirbystès institutas \\ ${ }^{2}$ Lietuvos agrarinių ir miškų mokslų centro Perlojos bandymų stotis
}

\section{Santrauka}

Rugių stiebalūžè, kurią sukelia patogenai Oculimacula yallundae ir O. acuformis, yra išplitusi daugelyje vėsaus klimato šalių. Tyrimų tikslas - ịvertinti stiebalūžès išplitimą žieminių rugių pasèliuose ịvairiose Lietuvos agroekologinėse zonose ir nustatyti patogenų $O$. yallundae bei $O$. acuformis kieki populiacijoje, taikant tikrojo laiko polimerazès grandininès reakcijos metodą. 2008-2012 m. buvo įvertinti 69 žieminių rugių pasèliai, iš kurių $92,7 \%$ buvo rasta stiebalūžès pažeistų rugių stiebų. Ligos išplitimas žieminių rugių pasėliuose įvairavo tarp ịvairių vietovių ir tyrimų metų (nuo 8,0 iki 82,7 \%). Vidutinis stiebalūžès išplitimas tirtuose pasėliuose buvo $26,0 \%$. Didžiausias stiebalūžěs išplitimas nustatytas Vidurio žemumos zonoje (vidutiniškai 34,0 \%). Abu - ir O. yallundae, ir O. acuformis - patogenai koegzistavo ant stiebalūžès pažeistų žieminių rugių stiebų. Oculimacula spp. kiekybinè tikrojo laiko polimerazès grandininès reakcijos analizė atlikta tiriant žieminių rugių stiebalūžès pažeistus stiebus, 2010-2012 m. surinktus iš įvairių Lietuvos agroekologinių zonų. Beveik visuose tirtuose rugių pasėliuose Oculimacula spp. populiacijoje vyravo $O$. acuformis. Daugeliu atvejų ant stiebalūžès pažeistų rugių stiebų buvo nustatyti labai maži kiekiai $O$. yallundae DNR.

Reikšminiai žodžiai: Oculimacula acuformis, O. yallundae, stiebalūžè, tikrojo laiko polimerazès grandininè reakcija, žieminiai rugiai. 